\title{
Determination of radon gas activity levels in drinking water in Ahlat/Bitlis
}

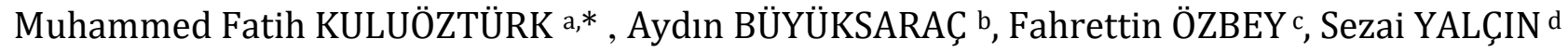 \\ a Bitlis Eren University, Department of Electrical-Electronics Engineering, TR-13000, Bitlis Turkey \\ b Bitlis Eren University, Department of Civil Engineering, TR-13000, Bitlis Turkey \\ c Bitlis Eren University, Department of Statistics, TR-13000, Bitlis Turkey \\ b Bitlis Eren University, Department of Physics, TR-13000, Bitlis Turkey
}

\section{ART I C LE INF O}

\section{Article history:}

Received 28 September 2017

Received in revised form 24 October 2017

Accepted 28 October 2017

Keywords:

Radon gas

Ahlat stone

Drinking water

\begin{abstract}
A B S T RAC T
Radon gas $\left({ }^{222} \mathrm{Rn}\right)$ that is a radioactive noble gas is second important reason of lung cancer. The penetration of the radon gas into the houses mostly takes place through the cracks in the building and tap water. Because of these reasons, radon gas detection in water is important for human health. In this study radon gas activity levels have been determined in a total of 14 tap water and spring water samples taken from different parts of Ahlat/Bitlis by AlphaGuard active radon detection system. Radon gas activities ranged from $3.16 \mathrm{Bql}^{-1}$ to $15.68 \mathrm{Bql}^{-1}$ and mean value is $10.11 \mathrm{Bql}^{-1}$.
\end{abstract}

(C) 2017. Turkish Journal Park Academic. All rights reserved.

\section{Introduction}

The radon gas, the only gas intermediate product of the ${ }^{238} \mathrm{U}$ natural decay chain, constitutes a large proportion of natural radioactivity. The radon has a half-life of 3.82 days and emits alpha particle with $4.89 \mathrm{MeV}$ energy. After entering the respiratory system, radon gas causes a very rapid decay mechanism to spread $\alpha$ and $\beta$ radiation (UNSCEAR, 2008). This decay mechanism also includes ${ }^{210} \mathrm{Po}$, a toxic radioisotope that leads to lung cancer.

The World Health Organization report stated that the second most important cause of lung cancer is radon (WHO, 2014). For this reason, radon gas is an important parameter that should be considered in terms of human health. Radon gas can threaten human health by being found in high concentrations in its ambient. It can be occurred by the concentration of $226 \mathrm{Ra}$ in the building materials, penetration of the radon gas from the ground through the voids and cracks in the ambient and dissemination of radon dissolved in tap water by ventilation (Duggal et al., 2017; Mittal et al,
2016). Because of its contribution to the radon concentration in the environment, it is important to determine the radon gas levels in the water (Singh et al., 2008).

In this study, radon gas activities were determined in tap water in Ahlat / Bitlis. Radon gas activities were measured using an AlphaGuard radon counter in 14 tap and spring water collected from different parts of Ahlat to cover the general population. Distribution map of radon gas in tap water was created by using measurement results. In addition, dose calculations were made using measured activity values.

\section{Material and Methods \\ 2.1. Study Area and Sampling}

Ahlat was built on sloping plateau overlooking Van Lake between Suphan and Nemrut mountains. It is located within the borders of Bitlis province (Fig.1). In Ahlat District, the volcano 'Ahlat Stone', which is a locality, removes and sells the Ahlat Stone by primitive methods under the angry sunshine of stone workers at the stone quarries under

\footnotetext{
* Corresponding author. 
the soil of the Nemrut Mountain skirts, 15 kilometers away from the town. Ahlat stone has a very strong structure due to the high amount of silica. Again, because of the abundant amount of oxygen and mineral water in contact with the air, they are separated from the stone over time. This decomposition is completed within 10-15 days after airborne contact. The colors of the stone are red, black, ash, white, gray, light yellow. The Ahlat township, consisting of a total of 10 districts, has spread over an area of approximately $14 \mathrm{~km}^{2}$. In this study, water samples were collected from drinking water sources as well as tap water samples from 15 houses made with Ahlat Stone. The samples taken in 1 liter volume polypropylene sample bottles were quickly brought to the laboratory and analyzed.
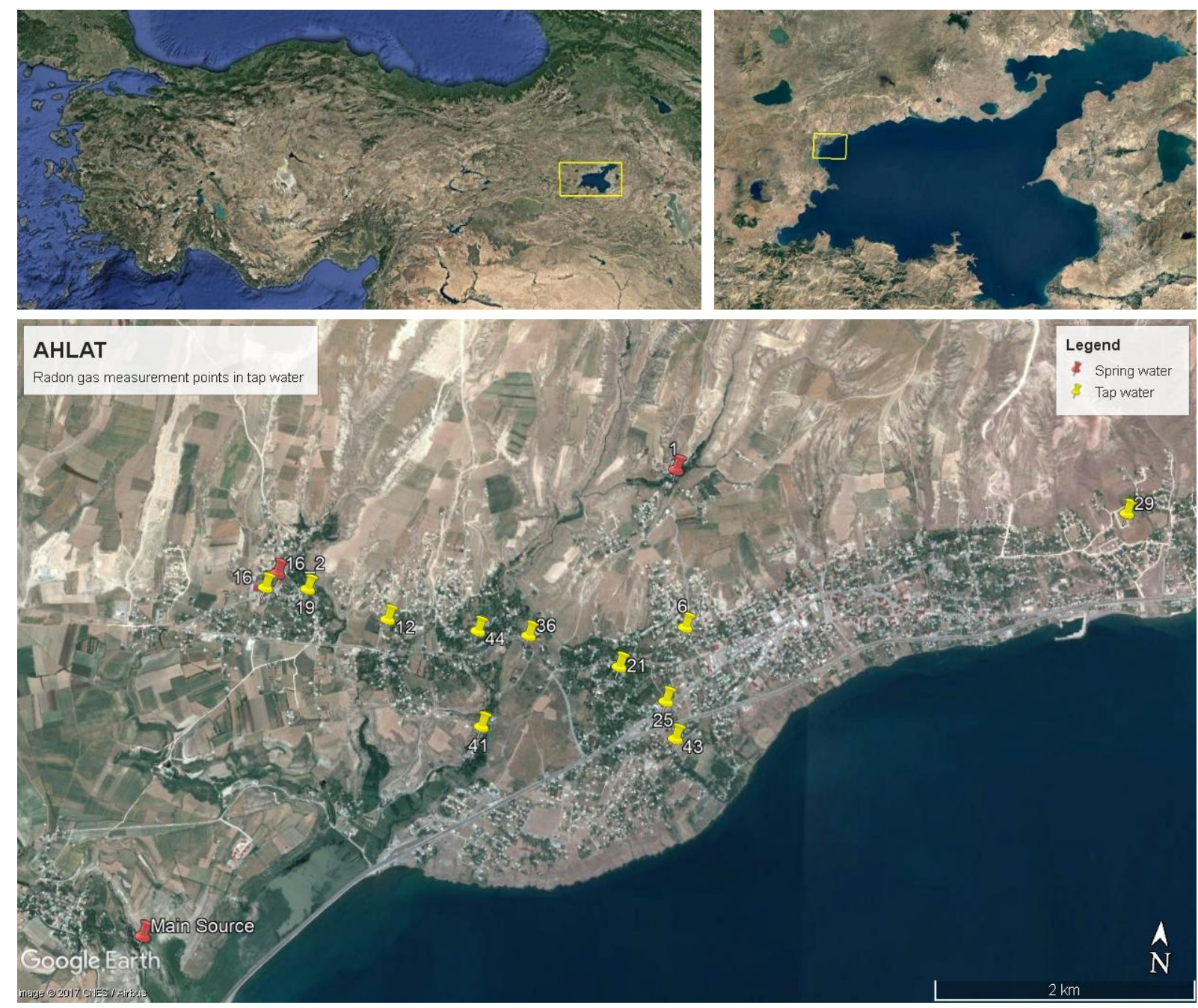

Figure 1. Location of Ahlat District on Turkey and Radon gas measurement points in Ahlat (Google Earth).

\subsection{Radon Measurement Procedure in Water}

In this study AlphaGUARD PQ2000 PRO radon measurement system was used for radon determination in water with AquaKIT and AlphaPUMP instruments (Fig.2). The AlphaGUARD has an ionization chamber with 0.56 liter active area and it runs with $750 \mathrm{~V}$ DC voltage supply. Alpha radiations emitted from radon are detected in this system.
Radon gas detection in water was performed according to the manufacturer's quick count procedure. Sample and background counts were performed three times for each samples. Sample volume for each counting is $100 \mathrm{ml}$. Background counts were made at 10 minute intervals without pumping. Sample counts were made in totally 30 minute intervals that pump runs at first 10 minutes and stops last 20 minutes (Schubert et al., 2006; Nikolopoulos D. and Luoizi A., 2008; Nikolopoulos D. et al., 2010; Meisenberg et al., 2017). 
Counting results are in $\mathrm{Bqm}^{-3}$ unit. Radon gas concentrations in water were calculated with following formula by using sample and background counts.

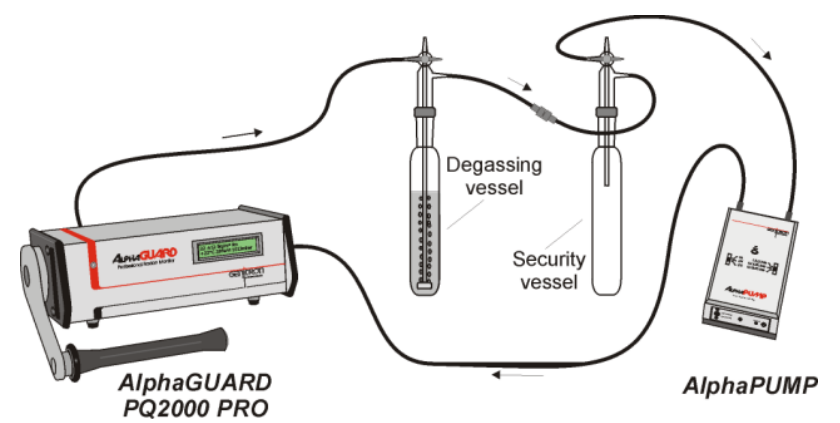

Figure 2. AlphaGUARD, AquaKIT and AlphaPUMP radon measurement system.

$$
C_{\text {water }}\left(B q l^{-1}\right)=\frac{C_{\text {air }}\left(\frac{V_{\text {system }}-V_{\text {sample }}}{V_{\text {sample }}}+k\right)-C_{0}}{1000}
$$

Where $\mathrm{C}_{\text {water, }} \mathrm{C}_{\text {air }}, \mathrm{C}_{0}, \mathrm{~V}_{\text {system}}, \mathrm{V}_{\text {sample }}$ and $\mathrm{k}$ are radon concentration in water $\left(\mathrm{Bql}^{-1}\right)$, measured radon activity (Bqm3 ), background activity $\left(\mathrm{Bqm}^{-3}\right)$, system volume $(560 \mathrm{ml})$, sample volume $(100 \mathrm{ml})$ and radon spread coefficient that varies depending on the temperature.

\section{Results and Discussion}

The measurement results of drinking water samples (11 from tap water, 3 from spring water) collected from different parts of Ahlat district of Bitlis/Turkey are tabulated in Table 1. Radon concentration results are varies from 3.95 Bq.l ${ }^{-1}$ to 10.36 Bq.l-1 mean 7.09 for spring water and 3.16 Bq. $\mathrm{l}^{-1}$ to 15.68 Bq.l ${ }^{-1}$ mean 11.29 for tap water. It's clear that mean radon concentration of spring water is less than tap water. This is a results of continuous ventilation of water due to the high flow of the spring water. USEPA (United States Environmental Protection Agency) has assigned the maximum radon concentration allowed in water to be 11 Bq.l-1 (USEPA, 1991). $73 \%$ of tap water samples were exceed this value, but the spring water samples were below this value.

Dose values were calculated from measured radon concentration values. The annual mean effective doses of drinking water samples caused ingestion and inhalation were calculated by using following formulas (UNSCEAR, 2000):

$$
\begin{gathered}
E_{\text {ing }}\left(n S v y^{-1}\right)=C_{R n} \times C_{w} \times(E D C) \\
E_{\text {inh }}\left(\mu S v y^{-1}\right)=C_{R n} \times R_{a . w} \times E F \times O \times(D C F)
\end{gathered}
$$

in first formula $E_{i n g}, C_{R n}, C_{w}$ and (EDC) are the annual effective dose caused ingestion, the radon activity in water $\left(\mathrm{Bql}^{-1}\right)$, water consumption for adult for a year (2 l.day $^{-1} \times 365$ day.year-1) and Effective Dose Coefficient for ingestion 3.5 nSvBq-1 respectively (Mittal, Rani, \& Mehra, 2016).

In the second formula $E_{i n h}, C_{R n}, R_{a . w}, E F, O$ and (DCF) are the effective dose due to inhalation, the radon activity in water $\left(\mathrm{Bql}^{-1}\right)$, ratio of the radon in air to radon in tap water $\left(10^{-4}\right)$, average indoor occupancy time per person (7000 hy-1) and Dose Conversion Factor for radon exposure $9 \mathrm{nSvh}^{-1}\left(\mathrm{Bqm}^{-3}\right)^{-1}$ respectively (Mittal et al., 2016).

The total annual effective doses of drinking water samples were calculated with summing of dose values due to ingestion and inhalation.

$$
E_{\text {water }}=E_{\text {ing }}+E_{\text {inh }}
$$

Total annual effective dose values were below the recommended value $100 \mu \mathrm{Sv}_{\mathrm{y}} \mathrm{-}^{-1}$ (WHO, 2017).

\section{Conclusions}

In the paper radon gas activity concentration levels in 14 drinking water samples collected from Ahlat district (Bitlis/Turkey) were determined by AlphaGuard PQ2000 PRO and its apparatus for detection in water.

From the radon gas activity concentration results for water samples, $57 \%$ of the samples exceeded the recommended level. Spring water samples were below the recommended level but 8 of 11 tap water samples (73\%) exceeded the recommended level. Additionally mean radon gas activity concentration is near to the recommended level. The calculated total annual effective dose values were also below the recommended level.

\section{Acknowledgements}

This study was supported by "Determination of indoor radon gas levels in some buildings which constructed with Ahlat stone in Ahlat/Bitlis" BEBAP (Bitlis Eren University Scientific Research Projects Coordination Unit) project (Project Number: BEBAP 2017.06).

\section{References}

Duggal V., Sharma S., Mehra R., 2017. Radon levels in drinking water of Fatehabad district of Haryana, India. Applied Radiation and Isotopes, 123, 36-40.

Meisenberg O., Mishra R., Joshi M., Gierl S., Rout R., Guoa L., Agarwal T., Kanse S., Irlinger J., Sapra B.K., Tschiersch J., 2017. Radon and thoron inhalation doses in dwellings with earthen architecture: Comparison of measurement methods. Science of the Total Environment, 579, 1855-1862.

Mittal S., Rani A., Mehra R., 2016. Radon levels in drinking water and soil samples of Jodhpur and Nagaur districts of Rajasthan, India. Applied Radiation and Isotopes, 113, 53-59. 
Table.1 Radon concentration in water samples in Ahlat district of Bitlis/Turkey

\begin{tabular}{|c|c|c|c|c|c|}
\hline \multirow{2}{*}{ Sample ID } & \multirow{2}{*}{ Sample Type } & \multirow{2}{*}{ Radon Activity (Bq. $\mathrm{l}^{-1}$ ) } & \multicolumn{3}{|c|}{$\begin{array}{l}\text { Annual mean effective dose } \\
\qquad\left(\mu S v \cdot y^{-1}\right)\end{array}$} \\
\hline & & & Ingestion & Inhalation & Total \\
\hline 1 & Spring Water & $3.95 \pm 0.20$ & 10.09 & 9.95 & 20.05 \\
\hline 6 & Tap Water & $14.59 \pm 0.11$ & 37.27 & 36.76 & 74.03 \\
\hline 12 & Tap Water & $13.35 \pm 1.65$ & 34.10 & 33.63 & 67.73 \\
\hline 16 & Tap Water & $10.99 \pm 1.54$ & 28.09 & 27.70 & 55.79 \\
\hline $16 \_2$ & Spring Water & $6.97 \pm 0.49$ & 17.81 & 17.56 & 35.37 \\
\hline 19 & Tap Water & $10.24 \pm 0.77$ & 26.15 & 25.80 & 51.95 \\
\hline 21 & Tap Water & $4.27 \pm 0.74$ & 10.91 & 10.76 & 21.67 \\
\hline 25 & Tap Water & $3.16 \pm 0.50$ & 8.07 & 7.95 & 16.02 \\
\hline 29 & Tap Water & $12.67 \pm 0.44$ & 32.36 & 31.92 & 64.28 \\
\hline 36 & Tap Water & $9.25 \pm 1.31$ & 23.63 & 23.31 & 46.94 \\
\hline 41 & Tap Water & $14.90 \pm 1.38$ & 38.08 & 37.56 & 75.63 \\
\hline 43 & Tap Water & $15.06 \pm 1.13$ & 38.48 & 37.95 & 76.43 \\
\hline 44 & Tap Water & $15.68 \pm 1.22$ & 40.05 & 39.51 & 79.56 \\
\hline Main Source & Spring Water & $10.36 \pm 0.28$ & 26.47 & 26.11 & 52.58 \\
\hline Min. & & 3.16 & 8.07 & 7.95 & 16.02 \\
\hline Max. & & 15.68 & 40.05 & 39.51 & 79.56 \\
\hline Mean & & 10.39 & 26.54 & 26.18 & 52.72 \\
\hline Limit Value & & 11 (USEPA, 1991) & & & 100 (WHO, 2017) \\
\hline
\end{tabular}

Nikolopoulos D., Louizi A., 2008. Study of indoor radon and radon in drinkingwater in Greece and Cyprus: Implications to exposure and dose. Radiation Measurements, 43, 1305-1314.

Nikolopoulos D., Vogiannis E., Petraki E., Zisos A., Louizi A., 2010. Investigation of the exposure to radon and progeny in the thermal spas of Loutraki (Attica-Greece): Results from measurements and modelling. Science of the Total Environment, 408, 495-504.

Schubert M., Buerkin W., Pena P., Lopez A.E., Balcazar M., 2006. Onsite determination of the radon concentration in water samples: Methodical background and results from laboratory studies and a field-scale test. Radiation Measurements, 41, 492-497.

Singh, J., Singh, H., Singh, S., Bajwa, B.S., 2008. Estimation of uranium and radon concentration in some drinking water samples. Radiat.Meas, 43, S523-S526.
UNSCEAR (United Nations Scientific Committee on the Effects of Atomic Radiations), 2000. Sources, effects and risks of ionizing radiation. United Nations, New York.

UNSCEAR (United Nations Scientific Committee on the Effects of Atomic Radiations), 2008. Report to General Assembly with Scientific annexes. United Nations Sales Publications. United Nations, New York.

USEPA (United States Environmental Protection Agency), 1991. Federal Register 40 Parts 141 and 142: national Primary Drinking Water Regulations; Radionuclides: proposed Rule. U.S. Government Printing Office.

WHO (World Health Organisation), 2014. World Cancer Report. ISBN (PDF) 978-92-832-0443-5.

WHO (World Health Organisation), 2014. Guidelines for Drinking Water Quality, Fourth Edition Incorporating the First Addendum. ISBN 978-92-4-154995-0. 